\title{
Efficacy of shoulder exercises on locoregional complications in women undergoing radiotherapy for breast cancer: clinical trial
}

\author{
Eficácia dos exercícios para ombro nas complicações loco-regionais em \\ mulheres submetidas a radioterapia para câncer de mama: ensaio clínico
}

Oliveira MMF', Gurgel MSC', Miranda MS², Okubo MA², Feijó LFA², Souza GA'

\begin{abstract}
Objective: To investigate the effect of shoulder exercises during radiotherapy in relation to prevention of locoregional physical complications: limitation of range of motion (ROM) and functional capacity, arm circumference and scar tissue adhesion. Methods: Sixty-six women without shoulder ROM impairment following breast cancer surgery that included complete axillary dissection were allocated to one of two groups: 32 in the physical therapy group (PG) $(52.7 \pm 10.2$ years), who underwent an exercise program; and 34 in the control group (CG) (48 \pm 10.1 years). Shoulder ROM, upper-limb circumference and functional capacity and scar tissue adhesion were evaluated at the beginning and end of radiotherapy and six months after completing radiotherapy. Results: The PG showed improvements in flexion and abduction ROM between the first and third evaluations (flexion from $164.77^{\circ} \pm 8.9^{\circ}$ to $167.98^{\circ} \pm 9.5^{\circ}$ and abduction from $168.56^{\circ} \pm 10.0^{\circ}$ to $175.62^{\circ} \pm 10.2^{\circ}$ ), which was not observed in the $C G$ (flexion from $167.06 \pm 06^{\circ}$ to $165.16^{\circ} \pm 9.2^{\circ}$ and abduction from $169.71^{\circ} \pm 10.1^{\circ}$ to $169.53^{\circ} \pm 12.8^{\circ}$ ). There was a statistically significant increase in ROM in the PG in relation to the $C G$ (flexion, $p=0.02$; and abduction, $p=0.004$ ). The circumference and functional capacity were similar between the groups and the frequency of scar tissue adhesion in the CG was twice that observed in the PG ( $48 \%$ versus $24 \%, p=0.04$ ). Conclusions: These results suggest that shoulder exercises favor maintenance of flexion and abduction ROM of the shoulder and minimize the incidence of scar tissue adhesion in women undergoing radiotherapy for breast cancer treatment.
\end{abstract} Article registered in the UMIN Clinical Trials Registry under the number R000001387.

Key words: breast cancer; radiotherapy; physical therapy; physical complications; scar tissue adhesions.

\section{Resumo}

Objetivo: Verificar o efeito da realização de exercícios para o ombro durante a radioterapia na prevenção de complicações físicas locoregionais: limitação da amplitude de movimento $(A D M)$ e da capacidade funcional, circunferência do braço e aderência cicatricial. Métodos: Sessenta e seis mulheres sem comprometimento de ADM de ombro no pós-operatório de cirurgia para câncer de mama com dissecção axilar completa foram alocadas em dois grupos, sendo 32 no grupo de fisioterapia (GF) (52,7 710,2 anos), o qual foi submetido

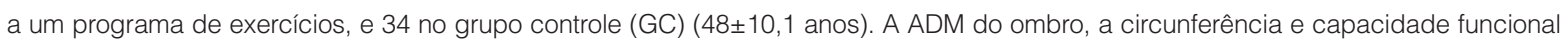
dos membros superiores e a aderência cicatricial foram avaliados no início e no final da radioterapia e seis meses após seu término. Resultados: O GF apresentou melhora da ADM de flexão e abdução entre a primeira e terceira avaliação (Flexão: de $164,77^{\circ} \pm 8,9^{\circ}$ para $167,98^{\circ} \pm 9,5^{\circ}$ e Abdução: $168,56^{\circ} \pm 10^{\circ}$ para $175,62^{\circ} \pm 10,2^{\circ}$ ), o que não se observou no GC (Flexão: $167,06^{\circ} \pm 6^{\circ}$ para $165,16^{\circ} \pm 9,2^{\circ}$ e Abdução: $169,71^{\circ} \pm 10,1^{\circ}$ para $169,53^{\circ} \pm 12,8^{\circ}$ ), demonstrando uma melhora significativa do GF em relação do GC (Flexão: $p=0,02$ e Abdução: $p=0,004)$. A circunferência e a capacidade funcional foram similares entre os grupos e a frequência de aderência cicatricial no GC foi o dobro daquela observada no GF (48\% e 24\%, $p=0,04)$. Conclusões: Esses resultados sugerem que exercícios para o ombro favorecem a manutenção da ADM de flexão e abdução de ombro e minimizam a incidência de aderência cicatricial em mulheres submetidas à radioterapia para tratamento por câncer de mama.

Artigo registrado no UMIN Clinical Trials Registry sob o número R000001387.

Palavras-chave: câncer de mama; radioterapia; fisioterapia; complicações físicas; aderência cicatricial.

Received: 30/04/2008 - Revised: 16/09/2008 - Accepted: 24/11/2008

Department of Obstetrics and Gynecology, School of Medicine, Universidade Estadual de Campinas (UNICAMP), Campinas (SP), Brazil

2Department of Physical Therapy, Women's Healthcare Center (CAISM), UNICAMP

${ }^{3}$ Department of Radiotherapy, CAISM, UNICAMP

Correspondence to: Profa. Dra. Maria Salete Costa Gurgel, Caixa Postal: 6081, CEP 13083-970, Campinas (SP), Brazil, e-mail: salete@caism.unicamp.br 


\section{Introduction : :}

Axillary lymphadenectomy associated with radiotherapy (RT) for breast cancer treatment is a matter for concern in most medical centers, because shoulder morbidity resulting from surgery and subcutaneous fibrosis (which is a biological effect from RT) results in limited shoulder range of motion (ROM) ${ }^{1-3}$. This ROM limitation is generally caused by fibrosis in the greater pectoral muscle and by vascular or joint damage ${ }^{4,5}$, loss of strength and muscle trophism ${ }^{1}$. Moreover, the risk of developing lymphedema ${ }^{6}$ due to subcutaneous fibrosis and changes in vessel and lymphatic capillary walls (thereby affecting local circulation ${ }^{7,8}$ ), may be 3.6 times higher in cases of axillary and supraclavicular RT. Lymphedema causes pain, discomfort, functional difficulty and changes in selfimage ${ }^{7-10}$. In addition, it affects the professional activities and quality of life $\mathrm{e}^{11,12}$ of these patients.

RT may present complications, depending on the radiation dose, radiation field used, influence of other types of treatment (chemotherapy and hormone therapy) and factors relating to the patient, such as age, body mass index (BMI) and professional activity ${ }^{4,12,13}$.

The objective of physical therapy following breast cancer surgery is to restore the patient's physical abilities, through preventing and reducing edema, conserving muscle strength and elasticity and conserving functional ROM. It is adopted both curatively and preventively as a strategy for restoring women's functional independence, reducing their anxiety levels and contributing towards improving their quality of life ${ }^{14}$.

The relevance of physical therapy following breast cancer surgery has been well documented in the literature ${ }^{3,14,15}$, although adequate programs and the timing of postoperative exercises have yet to be established ${ }^{5}$. However, despite the known physical complications resulting from RT, women are usually not provided with physical therapy during $\mathrm{RT}^{10,11,16,17}$. The hypothesis of this study was that the adoption of a rehabilitation program during RT could minimize its biological effect, with consequent functional improvement.

Therefore, the primary objective of this study was to determine whether supervised shoulder exercise during RT might offer some benefit for functional capacity and prevention of shoulder ROM limitation, while the secondary aim was to investigate the association of these exercises for preventing increases in homolateral upper limb circumference and scar tissue formation (adhesions) in women undergoing RT treatment for breast cancer.

\section{Methods :::}

A randomized, controlled clinical trial was carried out in the Department of Physical Therapy of the Women's
Integral Healthcare Center (CAISM) at Universidade Estadual de Campinas (UNICAMP), between May 2005 and September 2006. The sample size was calculated to be 56 , based on a study carried out by Gosselink et al. ${ }^{5}$, assuming an $\alpha$ error of $5 \%$ and a $\beta$ error of $20 \%$.

Seventy-two women were invited to participate in the study. All had undergone breast surgery for breast cancer and had received a manual containing instructions on arm care and routine activities, including illustrations and explanations of all exercises involving shoulder ROM to be performed at home. In addition, these women had taken part in a postoperative rehabilitation program, in accordance with the standard protocol in use within the Rehabilitation Program of the Physical Therapy Service of CAISM, which includes physical therapy sessions (three sessions per week for four weeks) and talks given by a multidisciplinary team (nurse, psychologist and social worker).

Women were included in this study if they presented a functional degree of ROM of the shoulder, which was defined as no deficit or less than $20^{\circ}$ of flexion and abduction deficit in relation to the contralateral shoulder ${ }^{16}$.

The following patients were excluded from the study: those who had undergone RT prior to surgery, those with upper limb lymphedema and/or shoulder ROM limitation prior to RT, those for whom physical exercise was medically contraindicated, those who had undergone bilateral breast surgery and those with local recurrence. Among the 72 eligible women, three $(4.1 \%)$ refused to participate in the study, declaring difficulty in attending the physical therapy sessions.

The project was approved by the Internal Review Board of UNICAMP (034/2005), and all the women signed an informed consent form.

\section{Intervention}

A sequence of computer-generated random numbers was used to allocate the patients to one of two groups. Among the women selected, 35 were enrolled in the physical therapy group (PG) during RT and 34 in the control group (CG), who did not undergo physical therapy during RT. Three women allocated to the PG were discharged between the first and second evaluations: two because of infection and chemotherapy complications and one who dropped out of the treatment. For this reason, their physical data were not considered in the analysis. Furthermore, six women (three in the PG and three in the CG) were unable to receive the third evaluation (three died and three moved to another address); their data were nonetheless included in the analysis (Figure 1).

The mean ages of the women in the two groups were similar (52.7 \pm 10.2 and $48.0 \pm 10.1$ years in the PG and CG, respectively; 
$\mathrm{p}=0.097)$ as were the mean BMIs $\left(27.9 \pm 5.1 \mathrm{~kg} / \mathrm{m}^{2}\right.$ in the PG and $24.7 \pm 4.9 \mathrm{~kg} / \mathrm{m}^{2}$ in the $\mathrm{CG} ; \mathrm{p}=0.833$ ). Table 1 shows the sociodemographic characteristics, clinical data and adjuvant treatment. No statistically significant difference was found between the two groups.

Modified radical mastectomy (Patey) was the most common surgical procedure performed (44.9\%). Dissection of all three axillary lymph node levels was performed in $94 \%$ of the women in the PG and $100 \%$ in the CG. RT was carried out in accordance with the protocol in use at the hospital. The radiation fields involved the breast or chest wall in all cases and the supraclavicular fossa in $71.6 \%$. A booster dose was applied to the tumor bed of 29 women (56.2\%).

Physical therapy sessions were started concomitantly with RT, on average 90 days after surgery. A total of 18 sessions were performed during the treatment period (45 minutes for each session, three times a week). The physical therapy technique was kinesiotherapy, composed of 19 exercises including

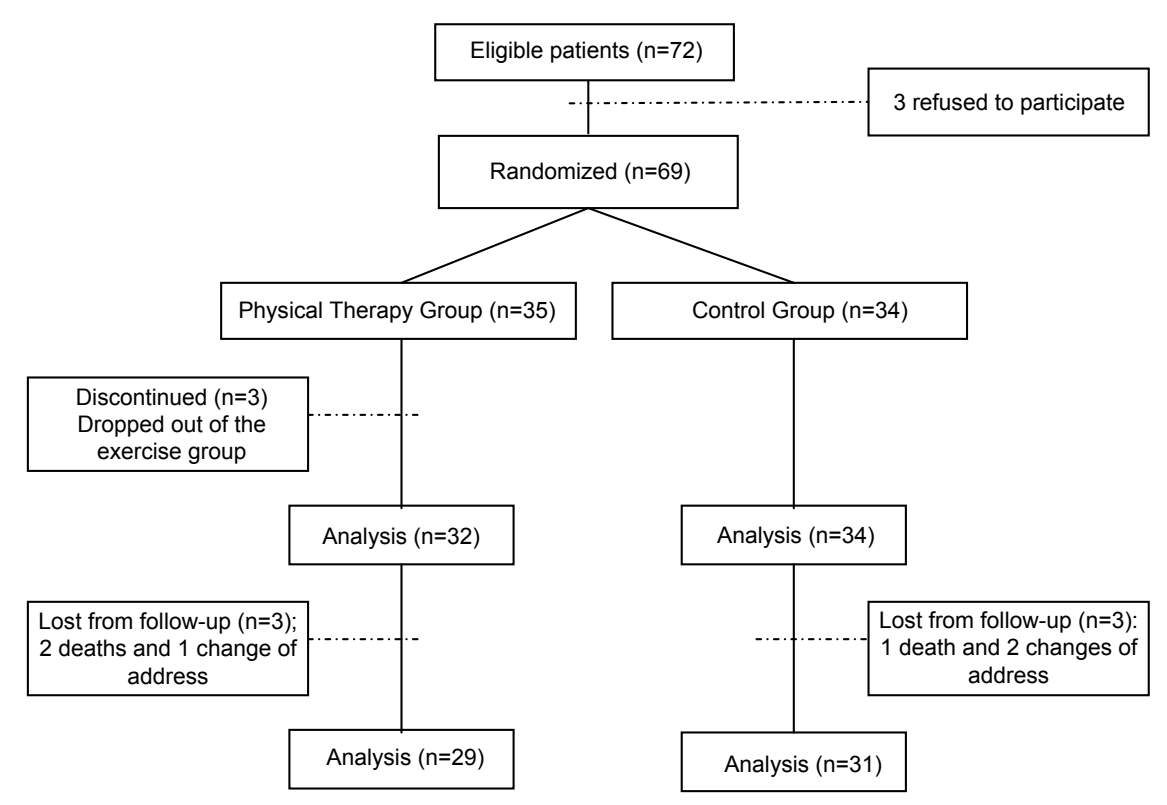

Figure 1. Flowchart for study sample.

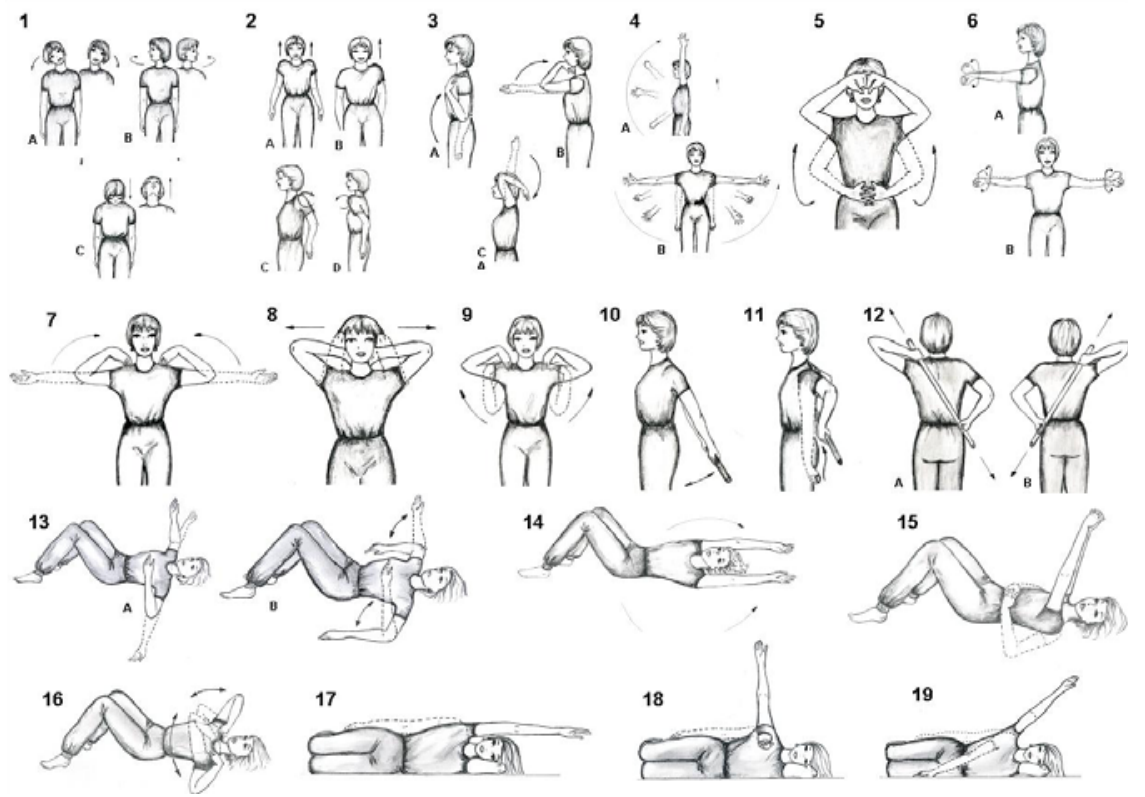

Source: Amaral et al. ${ }^{18}$

Figure 2. Illustration of exercises, including flexion, extension, abduction, adduction and internal and external rotation movements of the upper limbs. 
Table 1. Sociodemographic characteristics, clinical data and radiotherapy procedures according to group ( $\mathrm{N}=69$ ).

\begin{tabular}{|c|c|c|c|c|c|}
\hline & & 35) & & =34) & $P$ \\
\hline & $\mathrm{N}$ & $\%$ & N & $\%$ & 1 \\
\hline Age (years) & & & & & $0.2307^{\alpha}$ \\
\hline$\leq 39$ & 5 & 15.6 & 7 & 20.6 & \\
\hline $40-49$ & 7 & 21.9 & 13 & 38.2 & \\
\hline $50-59$ & 15 & 42.9 & 10 & 29.4 & \\
\hline$\geq 60$ & 8 & 25.0 & 4 & 11.8 & \\
\hline $\begin{array}{l}\text { Education level } \\
\text { (grade) }\end{array}$ & & & & & $0.3654^{\alpha}$ \\
\hline Illiterate & 1 & 2.8 & 3 & 8.6 & \\
\hline $1^{\text {st }}-4^{\text {th }}$ & 18 & 52.9 & 12 & 34.3 & \\
\hline $5^{\text {th }}-8^{\text {th }}$ & 9 & 26.5 & 8 & 22.9 & \\
\hline High school & 7 & 20.6 & 12 & 34.3 & \\
\hline Surgery & & & & & $0.7776 \infty$ \\
\hline RM & 23 & 65.5 & 24 & 70.6 & \\
\hline$Q+A$ & 12 & 37.5 & 10 & 29.4 & \\
\hline Stage & & & & & $0.3753^{\alpha}$ \\
\hline I & 4 & 11.4 & 6 & 17.6 & \\
\hline$\|$ & 10 & 28.6 & 14 & 41.2 & \\
\hline III & 20 & 57.1 & 14 & 41.2 & \\
\hline IV & 1 & 2.9 & 0 & 0.0 & \\
\hline Chemotherapy & & & & & $1.0000^{\alpha}$ \\
\hline Yes & 33 & 94.3 & 32 & 94.1 & \\
\hline No & 2 & 5.7 & 2 & 5.9 & \\
\hline Hormone therapy & & & & & $0.3351 \infty$ \\
\hline Yes & 15 & 42.9 & 18 & 52.9 & \\
\hline No & 20 & 57.1 & 16 & 47.1 & \\
\hline $\begin{array}{l}\text { Irradiation of } \\
\text { supraclavicular } \\
\text { fossa }\end{array}$ & & & & & $0.7279 \infty$ \\
\hline Yes & 23 & 69.7 & 26 & 76.5 & \\
\hline No & 10 & 30.3 & 8 & 23.5 & \\
\hline $\begin{array}{l}\text { Chest wall or } \\
\text { breast dose (cGs) }\end{array}$ & & & & & $0.7090^{\alpha}$ \\
\hline 4500 & 4 & 12.1 & 3 & 8.8 & \\
\hline 5000 or 5040 & 29 & 87.9 & 31 & 91.2 & \\
\hline Booster & & & & & $0.8888 \propto$ \\
\hline Yes & 14 & 42.4 & 15 & 44.1 & \\
\hline No & 19 & 57.6 & 19 & 55.9 & \\
\hline
\end{tabular}

$\infty$ Determined by chi-square test; ${ }^{\alpha}$ Determined by Fisher's exact test; RM: Radical mastectomy (including Halsted, Patey and Madden); Q+A: Quadrantectomy with axillary lymph node dissection; PG: Physical therapy Group; CG: Control Group. flexion, extension, abduction, adduction and internal and external rotation movements of the shoulders (Figure 2). Each exercise was performed individually or in combination ${ }^{15,18,19}$.

All exercises were performed with both arms in all physical therapy sessions. Exercises 1 to 14 and 16 were free active exercises, with one series of 10 repetitions. The remaining exercises $(15,17,18$ and 19) were aimed at maintaining the elasticity of the connective tissue, with 10 repetitions in each direction, and each repetition was maintained for 10 seconds $^{18}$.

A cobalt unit (CGR-MeV, Alcyon model) was used for radiation. The irradiated fields were the chest wall or breast at doses of 4500 or $5040 \mathrm{cGy}$, and the supraclavicular fossa at a dose of 5040 cGy. None of the women underwent axillary RT. Fractions of 180 cGy were applied daily, five days a week (Monday to Friday). A booster dose was applied to all cases of conservative surgery and exiguous mastectomy margins (less than $1 \mathrm{~mm}$ from the invasive carcinoma). In such cases, the dose was $1000 \mathrm{cGy}$ in five fractions of $200 \mathrm{cGy}$, applied to the tumor bed.

The first evaluation was performed after surgery and during the week prior to RT. It consisted of a physical examination to measure shoulder ROM during flexion, abduction and external rotation, measurement of the upper limb circumference, functional capacity and scar tissue formation (adhesions). The second evaluation was carried out at the end of RT and the third evaluation was carried out six months after RT treatment. The evaluations and physical therapy sessions were carried out by three trained qualified physical therapists.

\section{Measurements}

\section{Range of motion}

Shoulder ROM was evaluated by goniometry. Flexion and external rotation were measured with the patient in the supine position, while abduction was evaluated with the patient in the lateral position. The segment undergoing evaluation needed to be in the anatomical position, with the proximal segment stabilized so as to permit only the desired joint motion. The women were asked to perform active motion so as to reach the greatest range possible, and the angles were recorded in degrees ${ }^{17,19}$.

\section{Arm circumference}

Bilateral arm circumference measurements were made using a universal flexible tape measure (in centimeters). Five different levels of the upper limbs were measured: olecranon process, forearm (beginning at the olecranon process, $7.5 \mathrm{~cm}$ and $15 \mathrm{~cm}$ towards the hand), and upper arm (beginning at the olecranon process, $7.5 \mathrm{~cm}$ and $15 \mathrm{~cm}$ towards the shoulder $)^{14,19}$. The arm was in a relaxed position next to the body ${ }^{5}$. 


\section{Scar tissue formation (Adhesions)}

The technique to evaluate scar tissue formation (adhesions) followed the protocol of the Physical Therapy service. Thus, decreased skin distension of the scar tissue and abnormal tissue fixation around the scar tissue were subjectively evaluated by finger palpation of the scar and surrounding area with the patient undressed and at rest. Scar tissue (adhesion) was classified as present or absent.

\section{Functional capacity of the shoulder}

A subjective functional assessment was made, based on a scale used by Wingate ${ }^{14}$ relating to arm function and ROM of women with breast cancer. The patients were asked to compare the difficulty in performing six motions involving the shoulder (hooking a rear-fastening bra, reaching the ipsilateral scapula from below, reaching the contralateral scapula from above, making the bed, and carrying groceries weighing 3 to $4 \mathrm{~kg}$ ). The patients were asked to express their difficulty in performing each movement on a score ranging from 0 to 4 (none, slight, moderate, maximum or unable to perform the task, respectively). A final total score ranging from 0 to 24 was obtained by adding the evaluated topics. The lower the final score was, the greater the patient's functional capacity.

\section{Statistical analysis}

The chi-square test and Fisher's exact test were used to investigate the homogeneity of categorical variables between the groups. The t-test was used to compare ages and the Mann-Whitney test was used to compare the BMI between groups. The measurements of flexion, rotation and abduction were evaluated with the means for both shoulders (ipsilateral and contralateral) and with the difference between them. The data were tested for normal distribution using the Kolmogorov-Smirnov test and, if normality was detected, the three evaluations were compared by means of multivariate analysis of variance (MANOVA), using Wilk's test, to evaluate group and time effects between groups. Friedman's test was used for this in cases of non-normally distributed data. The significance level was set at $\mathrm{p}<0.05$. The software used for the analysis was SAS 9.1.3.

\section{Results $: \because$.}

\section{Range of motion}

Longitudinal ROM comparisons on the shoulder ipsilateral to the surgery, obtained from the three evaluations, revealed improved behavior in the PG compared with the CG, for flexion and abduction ( $p=0.02$ and 0.006, respectively) (Figure 3). No such improvement was observed regarding external rotation movements of the shoulder joint ( $p=0.71)$.

The patients in the PG presented increased flexion ROM, whereas the control patients had slightly decreased ROM, comparing the mean values at the beginning and end of RT $(p=0.007)$. Significant improvements in flexion and abduction ROM were found in the PG women compared with the control women ( $p=0.022$ and 0.021 , respectively) between the beginning of RT and six months after completion of RT. Finally, comparing ROM at the end of RT with the values obtained six months after RT, a significant improvement in abduction was

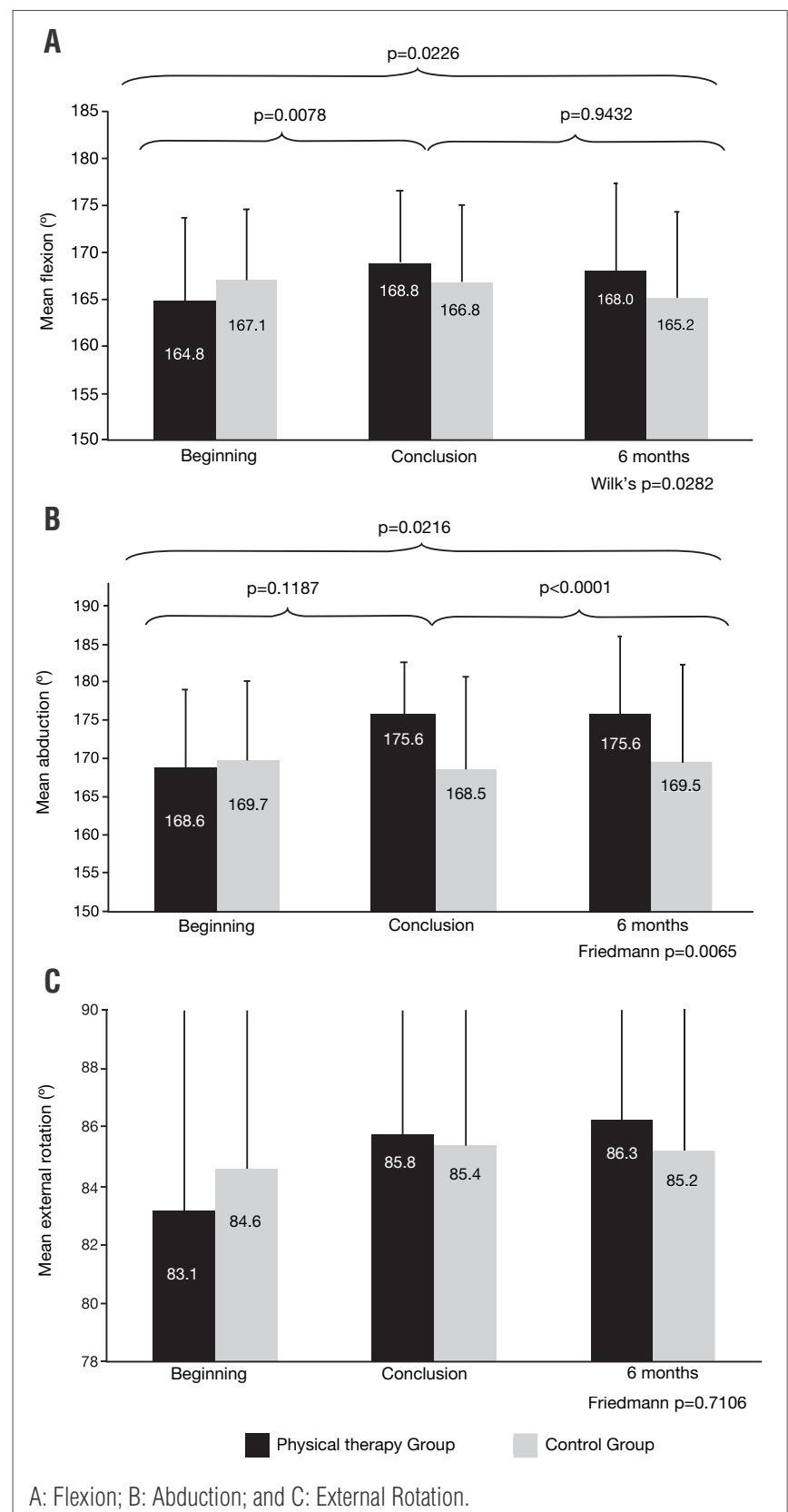

Figure 3. Mean shoulder ROM values at the beginning of radiotherapy, at its conclusion and six months later, according to group. 
observed in the PG women compared with those in the CG $(\mathrm{p}<0.0001)$. No such improvement was found regarding flexion movements (Figure 3).

At the beginning of RT, both groups presented a ROM deficit in the shoulder ipsilateral to the surgery in comparison to the contralateral shoulder, for flexion (PG: $-10.2^{\circ} \pm 9.2^{\circ}$; and CG: $-7.4^{\circ} \pm 11.2^{\circ}$ ) and abduction (PG: $-6.81^{\circ} \pm 18.5^{\circ}$; and CG $\left.-7.7^{\circ} \pm 9.8^{\circ}\right)$. This deficit was found to have decreased in the PG (flexion: $-5.8^{\circ} \pm 8.5^{\circ}$; and abduction: $-3.9^{\circ} \pm 12.7^{\circ}$ ) and increased in the CG (flexion: $-11.3^{\circ} \pm 13.4^{\circ}$; and abduction: $\left.-10.3^{\circ} \pm 19.7^{\circ}\right)$ at the last evaluation, thus demonstrating a statistically significant improvement in the PG in relation to the CG (Flexion: $\mathrm{p}=0.001$; and abduction: $\mathrm{p}=0.05$ ).

\section{Arm circumference}

No statistically significant differences in arm circumference measurements were found between the PG and CG women at the three evaluated times $(\mathrm{p}=0.15)$.

\section{Scar tissue (adhesion)}

The frequency of scar tissue formation (adhesion) was similar in the PG $(28 \%)$ and the CG $(27 \%)(p=0.9081)$ at the initial evaluation. A similar increase was found in both groups at the end of the RT (PG 68.8\%, CG 61.1\%; p=0.4021). However, the evaluation performed six months after RT showed that the women who had not undergone physical therapy presented increased frequency of scar tissue formation (adhesion) (48.8\%), while those who had undergone supervised shoulder exercises presented decreased frequency $(24 \%)(p=0.04)$.

\section{Functional capacity}

There was no statistically significant difference $(p=0.43)$ in functional capacity between the groups. However, the women in the PG initially had greater difficulty in performing the activities requested, compared with the women in the CG. At the end of RT, there was a reversal in this behavior, such that the control women had more difficulty than the women in the PG. Six months later, the women in the PG had less difficulty in carrying out the movements than in the evaluation prior to radiotherapy. In contrast, the mean functional capacity score of the control women increased in relation to the first evaluation, thus indicating a trend towards greater difficulty in carrying out the activities (Table 2).

Initially, $55.5 \%$ of the women in the PG reported no difficulty in carrying out the activities, and these percentages increased at the second and third evaluations (59.7\% and $66 \%$, respectively). However, in the CG these percentages
Table 2. Mean functional capacity score at the beginning of radiotherapy, at its conclusion and six months later, according to group.

\begin{tabular}{lcccc} 
& \multicolumn{2}{c}{$\mathrm{PG}$} & \multicolumn{2}{c}{$\mathrm{CG}$} \\
& $\mathrm{n}$ & Mean \pm SD & $\mathrm{n}$ & Mean \pm SD \\
\hline Beginning & 32 & $5.5 \pm 5.7$ & 34 & $3.6 \pm 4.4$ \\
\hline Conclusion & 32 & $4.3 \pm 4.7$ & 34 & $3.4 \pm 4.3$ \\
\hline 6 months & 29 & $4.0 \pm 5.6$ & 31 & $5.0 \pm 5.3$ \\
\hline
\end{tabular}

PG: Physical therapy Group; CG: Control Group.

decreased throughout the follow-up period $(65.7 \%, 65.7 \%$ and $58 \%$, respectively).

\section{Discussion : $:$.}

This study was carried out among women undergoing RT for breast cancer treatment. Comparisons were made between two different groups. The women in the first group (PG) were given supervised shoulder exercises during RT while those in the second group (CG) were not.

Mechanical stimulation by free active exercises and stretching may minimize the functional damage triggered by RT during the process of tissue repair ${ }^{18}$. Exercises also provide mobility and flexibility to the soft tissues surrounding the joint ${ }^{18}$.

The present analysis suggests that shoulder exercises (active exercising and stretching), applied during RT for breast cancer treatment, prevents limitations of shoulder ROM relating to flexion and abduction, minimizes the incidence of scar tissue formation (adhesions) and encourages improvement in functional capacity. However, over the period of this study, no association was found between exercise and changes in arm circumference.

Women with full ROM function prior to RT have been reported to have a $24 \%$ chance of developing persistent problems with shoulder movement, due to changes in muscles and soft tissue ${ }^{20}$. In our study, a statistically significant difference in ROM between the groups studied was observed, with reductions in ROM function relating to flexion and abduction at the end of RT and six months after completion of RT in the CG, and increased ROM in the PG. The mean decrease in flexion ROM in the CG had a small clinical impact, given that this difference did not influence the performance of daily activities. In contrast, the increased ROM found in the PG benefited the stretching of the tissues involved (muscle, fascia, tendon and skin), thereby preventing complications and contributing towards the performance of daily activities.

Blomqvist et al. ${ }^{17}$ evaluated 75 women who had undergone modified radical mastectomy ( 30 of them received RT) and found that radiation was the greatest cause of impaired ROM. These investigators concluded that patients undergoing RT should be 
encouraged to participate in routine rehabilitation programs, thereby gaining from intensive physical therapy over a longer period of time ${ }^{17}$. These findings are in agreement with our results, which found improvements in ROM relating to flexion and abduction among the patients in the PG during RT, and this improvement was maintained after the six-month follow-up period.

Hwang et al. ${ }^{3}$ reported that after radiotherapy, shoulder ROM in all directions increased in the exercise group and decreased in the control group. However, a study conducted to investigate whether a stretching program would reduce acute musculoskeletal impairments among patients undergoing radiotherapy for breast cancer, with shoulder ROM, strength, arm circumference and quality of life measured before and at the end of RT, and seven months after RT, reported that breast symptoms increased in both groups (control and pectoral stretching) during RT, without loss of strength or $\mathrm{ROM}^{1}$. The authors believed that the pectoral stretching program did not influence the outcomes measured because the symptoms reported by the patients were not a consequence of contracture ${ }^{1}$.

There is contradictory data in the literature regarding RT and the development of lymphedema ${ }^{9-11,21}$. Morrell et al. ${ }^{22}$ reported that adjuvant RT applied to the breast or lymph nodes increased the risk of lymphedema, which was present in 9-40\% of patients ${ }^{22}$. In a randomized clinical trial conducted on 381 women undergoing segmentectomy and axillary lymph node dissection, it was found that radiation restricted to the breast resulted in no adverse effect on the arm during the first three years following surgery ${ }^{23}$.

In our study, the mean circumferential measurements of the arms remained stable throughout the follow-up in both groups, thus suggesting that RT was not associated with the risk of developing lymphedema during the period studied. However, this period is considered insufficient, because studies have shown that the prevalence of lymphedema increases with length of time since radiotherapy, ranging from $0-23 \%$ in the first two years to $45 \%$ after 15 years or more ${ }^{24}$.

Scar tissue formation (adhesion) was present at the beginning of the study in similar proportions in both groups. However, in the evaluation performed six months after RT, the prevalence of scar tissue formation (adhesion) in women who had not done supervised shoulder exercises during RT was twice that of the women in the control group.

The lower rate of scar tissue formation (adhesion) in the PG may be related to the improved ROM achieved by women in this group, because additional physical therapy during RT or shortly afterwards encouraged patients to move their shoulders through the full range. Adherence between muscles, subcutaneous tissue and skin in the axillary and pectoral regions mechanically inhibits shoulder movement, and RT and chemotherapy increase the strong fibrotic connections between these structures ${ }^{25}$.
Stretching the scar tissue and muscles reduces the strong connection between the skin and underlying tissue and reduces muscle limitation, thereby improving shoulder mobility ${ }^{25}$.

Some studies consider that physical therapy prior to radiation is insufficient, given that approximately $50 \%$ of women undergoing RT report substantial impairment of arm function three months after surgery, due to slow healing of the scar tissue and accentuated tissue fibrosis triggered by RT ${ }^{5}$. These findings indicate that greater attention should be given to follow-up physical therapy for preventing morbidity ${ }^{5,26}$.

In the PG, in which the women performed supervised shoulder exercises, the mean number of women who reported no difference in performing the activities requested in the pre-RT evaluation increased in the final evaluation, thus indicating that there was less difficulty at the latter time. Among the women who did not participate in the physical therapy program, this percentage decreased between these evaluations. The trend towards improved functional capacity recorded in the final evaluation in the PG may be related to the better ROM found in this group. In addition, the self-confidence and stimulation resulting from contact with health professionals and other women in the group could be an important factor, given that daily interaction with healthcare workers offered patients a sense of support ${ }^{27}$.

In contrast, it may be hypothesized that when experiencing the painful effects of $\mathrm{RT}^{10}$, the women in the CG accepted restrictions on their mobility and tried to compensate for this limitation by using the contralateral arm or changing their working habits.

\section{Limitation}

The assessment made six months after completing the RT minimized the interference of acute effects on the physical complications evaluated. However, there were limitations on the present study, as physical complications may appear over a mean latency period of four years ${ }^{28}$. Therefore, the interval used in this study may have been too short to detect the late effects of radiation, such as the development of lymphedema and subcutaneous fibrosis 9 . A longer follow-up period might be appropriate for assessing whether the promising results from the physical therapy performed during RT in the present study would persist.

Another limitation was that the physical therapists were not blinded to the allocation groups because these professionals supervised the exercise sessions for six weeks during RT. Thus, successful blinding of the examiner was not accomplished. This failure of blinding was compensated for by scheduling appointments for both the intervention and the control group on the same days and by scheduling appointments on the same day for patients with different follow-up visits. 


\section{Conclusions : $:$.}

The results from this study support the proposal to provide physical therapy during RT, consisting of shoulder exercises.
Physical therapy favors the maintenance of shoulder ROM in relating to flexion and abduction and minimizes the occurrence of scar tissue formation (adhesion) in women with breast cancer, during the first six months of follow-up.

\section{References: : :}

1. Lee TS, Kilbreath SL, Refshauge KM, Pendlebury SC, Beith JM, Lee MJ. Pectoral stretching program for women undergoing radiotherapy for breast cancer. Breast Cancer Res Treat. 2007;102(3):313-21.

2. Lee TS, Kilbreath SL, Refshauge KM, Herbert RD, Beith JM. Prognosis of the upper limb following surgery and radiation for breast cancer. Breast Cancer Res Treat. 2008;110(1):19-37.

3. Hwang JH, Chang HJ, Shim YH, Park WH, Park W, Huh SJ, et al. Effects of supervised exercise therapy in patients receiving radiotherapy for breast cancer. Yonsei Med J. 2008;49(3):443-50.

4. Soran A, D'Angelo G, Begovic M, Ardic F, Harlak A, Samuel Wieand H, et al. Breast cancer-related lymphedema-what are the siginificant predictors and how they affect the severity of lymphedema? Breast J. 2006;12(6):536-43.

5. Gosselink R, Rouffaer L, Vanhelden P, Piot W, Troosters T, Christiaens MR. Recovery of upper limb function after axillary dissection. J Surg Oncol. 2003;83(4):204-11.

6. Ververs JM, Roumen RM, Vingerhoets AJ, Vreugdenhil G, Coebergh JW, Crommelin MA, et al. Risk, severity and predictors of physical and psychological morbidity after axillary lymph node dissection for breast cancer. Eur J Cancer. 2001;37(8):991-9.

7. Passik SD, McDonald MV. Psychosocial aspects of upper extremity lymphedema in women treated for breast carcinoma. Cancer. 1998;83(12): 817-20.

8. Herskind $\mathrm{C}$, Johansen J, Bentzen SM, Overgaard M, Overgaard J, Bamberg $\mathrm{M}$, et al. Fibroblast differentiation in subcutaneous fibrosis after postmastectomy radiotherapy. Acta Oncol. 2000;39(3):383-8.

9. Herd-Smith A, Russo A, Muraca MG, Del Turco MR, Cardona G. Prognostic factors of lymphedema after primary treatment of breast carcinoma. Cancer. 2001;92(7):1783-7.

10. Erickson VS, Pearson ML, Ganz PA, Adams J, Kahn K. Arm edema in breast cancer patients. J Natl Cancer Inst. 2001;93(2):96-111.

11. Johansen J, Overgaard J, Blichert-Toft M, Overgaard M. Treatment of morbidity associated with the management of the axilla in breast-conserving therapy. Acta Oncol. 2000;39(3):349-54.

12. Bentzen SM, Dische S. Morbidity related to axillary irradiation in the treatment of breast cancer. Acta Oncol. 2000;39(3):337-47.

13. Senkus-Konefka E, Jassem J. Complications of breast-cancer radiotherapy. Clin Oncol. 2006;18(3):229-35.

14. Wingate L, Croghan I, Natarajan N, Michalek AM, Jordan C. Rehabilitation of the mastectomy patient: a randomized, blind, prospective study. Arch Phys Med Rehabil. 1989;70(1):21-4.

15. Pinto e Silva MP, Derchain SFM, Rezende L, Cabello C, Martinez EZ. Movimento do ombro após cirurgia por carcinoma invasor de mama: estudo randomizado prospectivo controlado de exercícios livres versus limitados a 90 no pós-operatório. RBG0. 2004;26(2):125-30.

16. Deutsch M, Flickinger JC. Shoulder and arm problems after radiotherapy for primary breast cancer. Am J Clin Oncol. 2001;24(2):172-6.

17. Blomqvist L, Stark B, Engler N, Malm M. Evaluation of arm and shoulder mobility and strength after modified radical mastectomy and radiotherapy. Acta Oncol. 2004;43(3):280-3.

18. Amaral MTP, Teixeira LC, Dercahin SFM, Nogueira MD, Pinto e Silva MP, Gonçalvez AV. Orientação domiciliar: proposta de reabilitação física para mulheres submetidas à cirurgia por câncer de mama. Rev Cienc Méd. 2005; 14(5):405-13.

19. de Rezende LF, Franco RL, de Rezende MF, Beletti PO, Morais SS, Gurgel MS. Two exercise schemes in postoperative breast cancer: comparison of effects on shoulder movement and lymphatic disturbance. Tumori. 2006;92(1):55-61.

20. Sugden EM, Rezvani M, Harrison JM, Hughes LK. Shoulder movement after the treatment of early stage breast cancer. Clin Oncol (R Coll Radiol). 1998;10(3):173-81.

21. Nesvold IL, Dahl AA, Lokkevik E, Marit Mengshoel A, Fosså SD. Arm and shoulder morbidity in breast cancer patients after breast-conserving therapy versus mastectomy. Acta Oncol. 2008;47(5):835-42.

22. Morrell RM, Halyard MY, Schild SE, Ali MS, Gunderson LL, Pockaj BA. Breast cancer-related lymphedema. Mayo Clin Proc. 2005;80(11):1480-4.

23. Mortimer P, Bates D, Brassington H, Stanton A, Strachan D, Levick J. The prevalence of arm oedema following treatment for breast cancer. QJM. 1996;89(5):377-80.

24. Gerber L, Lamppert M, Wood C, Duncan M, D'Angelo T, Schain W, et al. Comparison of pain, motion and edema after modified radical mastectomy vs. local excision with axillary dissection and radiation. Breast Cancer Res Treat. 1992;21(2):139-45.

25. Lauridsen MC, Christiansen $P$, Hessov I. The effect of physiotherapy on shoulder function in patients surgically treated for breast cancer: a randomized study. Acta Oncol. 2005;44(5):449-57.

26. Demar R, Aitken MD, Minton MD. Complicações associadas com mastectomia. Simp Comp Proc C. 1986:1415-37. 
27. Wengström Y, Häggmark C, Strander H, Forsberg C. Perceived symptoms and quality of life in women with breast cancer receiving radiation therapy. Eur J Oncol Nurs. 2000;4(2):78-88.
28. Bergmann A, Pereira TB, Ribeiro ACP, Bourrus N, Silva JG. Prevalência de patologias de ombro no pré-operatório de câncer de mama: importância para a prevenção de complicações. Fisioter Bras. 2007;8(4):249-54. 